\title{
Prevalência e evidência etiopatogênica do Helicobacter pylori na doença parenquimatosa crônica de fígado
}

\author{
Marcos Clarêncio B. Silva* \\ Luis Antônio Rodrigues de Freitas** \\ Raimundo Paraná***
}

\begin{abstract}
Resumo
Helicobacter pylori é uma bactéria que participa na patogenia de algumas doenças gastroduodenais, como gastrites, doença ulcerosa péptica e neoplasias tipo linfoma MALT. A erradicação desta bactéria vem contribuindo para o controle destas patologias. No momento, buscam-se evidências que demonstrem a relação do Helicobacter pylori com outras doenças não gastroduodenais. O presente trabalho é uma revisão dos estudos sobre a prevalência da infecção por Helicobacter pylori em pacientes portadores de doença parenquimatosa crônica do fígado (DPCF), assim como dos que sugerem alguma participação etiopatogênica do Helicobacter pylori na evolução de pacientes portadores de DPCF. Após uma busca no banco de dados do Medline, no período de janeiro de 1990 a dezembro de 2002, observa-se que vários autores referem uma alta prevalência do Helicobacter pylori em pacientes com DPCF, mas o tamanho amostral e a metodologia utilizada foram insuficientes para validação externa. Embora o racional teórico exista, não há comprovação de que esta bactéria contribua para o surgimento de inflamaçôes crônicas no fígado ou progressão da fibrose hepática.
\end{abstract}

Palavras-chave: Cirrose. Helicobacter pylori.

\section{INTRODUÇÃO}

Helicobacter pylori (H. pylori) é uma bactéria gram-negativa, microaerófila, descoberta em 1983 pelos pesquisadores Warren e Marshall (1983). Na ocasião, eles observaram que esta bactéria infectava a mucosa gástrica e causava gastrite. Posteriormente, constatou-se uma estreita relação de $H$. pylori com úlcera péptica (UP) (PUERA, 1997) e também com câncer gástrico e linfoma de tecido linfóide associado à mucosa gástrica (MALT) (MIYAJI et al., 1997; TALLEY et al., 1991; BLASER et al., 1993;
PARSONNET et al., 1994). Tornou-se imperativo o tratamento do $H$. pylori em pacientes com UP e, com isso, houve uma diminuição acentuada da recidiva desta entidade e de suas complicações (VAN DER HULST et al., 1996; COELHO, 2001). Hoje existe uma preocupação na literatura em correlacionar o $H$. pylori com algumas patologias não gastroduodenais, tais como doença arterial coronariana, patologia dermatológica, respiratória, diabetes mellitus, doença do refluxo gastroesofágico, doença inflamatória intestinal e doença parenquimatosa crônica de fígado (DPCF) (EKSTRÖM, 1998).

\footnotetext{
* Aluno do Programa de Mestrado do CPgMS-UFBA.

Centro de Hemorragia Digestiva do Hospital Geral Roberto Santos, Salvador - BA

Av Juracy Magalhães Jr 2096 Sala 510, Salvador BA 41.920-000

E-mail: marcosclarencio@bol.com.br

** Centro de Pesquisa Gonçalo Muniz, FIOCRUZ-BA.

*** Serviço de Gastro-Hepatologia da UFBA.
} 
O paciente portador de DPCF tem uma maior predisposição a infecçôes por ter alterações nos mecanismos de defesa, tais como no sistema reticuloendotelial, na função dos polimorfonucleares, com baixos níveis de complemento, defeitos nos mecanismos de opsonização e deterioração da imunidade celular (DE NARDO et al., 1976; ALMEIDA, 2000). A maioria das infecçôes que acometem os pacientes com DPCF são por bactérias gram-negativas ou gram-positivas capsuladas. Dentre as principais infecções que acometem o paciente cirrótico, destaca-se a peritonite bacteriana espontânea (PBE) com incidência de 7\% a 23\% (RIMOLA, 1991; CALY; STRAUSS, 1993), infecção do trato urinário (CALY; STRAUSS, 1993; TOLEDO et al., 1994) e infecções do trato respiratório (CALY; STRAUSS, 1993; TOLEDO et al., 1994).

A mucosa gástrica no paciente com DPCF está predisposta a ter danos por apresentar redução dos níveis de prostaglandinas, alteração de secreção de muco e redução da secreção de bicarbonato (VERGARA; CALVET; ROQUÉ, 2002). Desse modo, o cirrótico tem maior susceptibilidade a doenças pépticas. Kataev e colaboradores (1990) revelaram, em uma das primeiras referências sobre a freqüência de $H$. pylori em DPCF — na ocasião ainda com a denominação de Campylobacter pylori —, a incidência de 47,3\% em cirróticos. Apesar da elevada frequiência de infecção pelo $H$. pylori em cirróticos, não foi possível qualquer inferência sobre seu papel etiopatogênico na fibrose hepática.

Posteriormente, alguns estudos sugeriram que a infecção pelo $H$. pylori no trato portal possa estimular a produção de interleucinas (IL1; IL6), TNF alfa e molécula adesina intercelular 1 (ICAM-1), o que poderia, teoricamente, explicar o aparecimento de inflamação crônica do fígado ou estimular a fibrogênese hepática (PONZETTO et al., 2000; YOSHIDA et al., 1995; CRABTREE et al., 1995).

O propósito deste artigo de revisão é mostrar qual a prevalência do $H$. pylori nos pacientes com DPCF, e se há evidência de este microorganismo causar doença hepática crônica per si.

\section{PREVALÊNCIA E EVIDÊNCIA ETIOPATOGÊNICA DO H. PYLORI NA DPCF}

Realizada uma busca, no banco de dados do Medline, especialmente de artigos de caso controle e de prevalência, no período de janeiro de 1990 a dezembro de 2002, utilizando as palavras-chave cirrose e Helicobacter pylori, em humanos, com os idiomas inglês, espanhol e português como línguas principais, foram localizadas 102 referências bibliográficas. Destas, foram selecionados 46 artigos que serviram de base para a presente revisão.

A prevalência de infecção pelo $H$. pylori nesses pacientes tem uma variação ampla nos estudos da literatura médica. Scotiniotis e colaboradores (2001) revelaram prevalência de 20\% em uma série de 69 pacientes com cirrose. Outros autores encontraram prevalência de aproximadamente $77 \%$ em cirróticos, comparados a 59\% no grupo controle (PONZETTO et al., $2000)$.

Sorologia positiva para $H$. pylori em cirróticos, anti-H. pylori IgG, mostrou-se elevada em comparação com a de doadores de sangue que fizeram parte da amostra $(76,5 \% \mathrm{x}$ $41,8 \%, \mathrm{p}<0,0005)$ (SIRINGO et al., 1997). Outro estudo transversal detectou uma freqüência de $89 \%$ em 45 pacientes com vírus B positivo, enquanto, no grupo controle de 310 indivíduos, foram registrados 59\% (VAN NIEUWKERK; KUIPERS, 2000).

Já Zullo e colaboradores (1999) encontraram, na Itália, prevalência de $60 \%$ em grupo controle, índice semelhante ao de portadores de DPCF por vírus B e C. Spinzi e colaboradores (2001), em estudo transversal, detectaram, em 52 pacientes com DPCF por vírus C, uma freqüência de $H$. pylori em 86,5\% (45/52).

Em outro estudo, tipo caso controle, em pacientes com hepatite autoimune, a prevalência foi de 64,5\% (31 pacientes) e de 53,2\% (62 pacientes) no grupo controle formado por doadores de sangue, não se constatando diferença estatística entre os grupos (DURAZZO et al., 2002). 
Por outro lado, sabe-se que a freqüência de úlcera péptica em pacientes com DPCF varia de $10 \%$ a $30 \%$, sendo mais elevada do que na população geral (VAN NIEUWKERK; KUIPERS, 2000; ZULLO et al., 1999; KUIPERS; THIJS; FESTEN, 1995). Van Nieuwkerk e Kuipers (2000) demonstraram que $H$. pylori é um fator de risco para desenvolvimento de úlcera péptica em cirróticos, sendo este risco 4 a 10 vezes maior do que em pacientes com $H$. pylori negativo. Pellicano e colaboradores (2000) demonstraram também alta prevalência de $H$. pylori em pacientes com DPCF, podendo-se, desse modo, explicar a freqüência aumentada de doença ulcerosa péptica em cirróticos. Vergara, Calvet e Roqué (2002), em uma metanálise, também afirmam que a infecção pelo $H$. pylori aumenta o risco de úlcera péptica nos pacientes com cirrose.

Tsai (1999), em um estudo observacional, revelou que a prevalência de $H$. pylori ou doença ulcerosa péptica é independente da gravidade da DPCF. Alguns estudos afirmam existir aumento dos níveis de amônia sérica nos pacientes cirróticos infectados por $H$. pylori e na secreção gástrica em pacientes com DPCF e $H$. pylori positivo (CHO et al., 1997; ATTILI et al., 1994; AL-KAREEMY; ZAKHARY, 1996; SI et al., 2000). Este achado sugere que a infecção por H. pylori pode contribuir ou mesmo desencadear encefalopatia hepática. Em contrapartida, outros autores não confirmam essa relação (ROSSLE et al., 1994; PLEVRIS et al., 1995; CHAKRABARTI et al., 2002; DEMIRTURK et al., 2001; KINI et al., 2001; MIQUEL et al., 2001; CALVET et al., 2002).

Outras espécies de Helicobacter, dentre elas o Helicobacter hepaticus (H. hepaticus), têm sido referidas como agentes que poderiam participar na patogênese da cirrose hepática, da hepatite crônica, da colangite esclerosante e do carcinoma hepatocelular, contudo a confirmação desta hipótese está ainda longe de ser alcançada (NILSSON; LINDGREN; WADSTRÖM, 2000; AVENAUD et al., 2001; O'ROURKE; GREHAN; LEE, 2001; FAGOONEE et al., 2001). Foram observados níveis elevados de anticorpos contra $H$. hepaticus em pacientes com
DPCF (56 de 144 - 39\%) e em portadores de colangite esclerosante primária (6 de 30 - 20\%). Freqüentemente, existe reação cruzada na detecção de anticorpos de $H$. pylori e $H$. hepaticus, fato que torna ainda mais complexa a interpretação deste achado (NILSSON et al., 2001).

Dore e colaboradores (2002) também demonstraram a presença de espécies de Helicobacter em tecido hepático em pacientes com doença crônica causada pelo vírus C, sugerindo uma possível relação. Por outro lado, notou-se que a carga bacteriana do $H$. pylori na mucosa gástrica é mais intensa em portadores de DPCF do que em pacientes sem doença crônica hepática (STALKE et al., 2001). Porém Calvet e colaboradores (2002) revelaram que a etiologia e a gravidade da DPCF não se correlacionam com a presença do $H$. pylori.

\section{A ESPÉCIE HELICOBACTER NAS AFECÇÔES GASTRODUODENAIS E NA DPCF}

O H. pylori tem importante papel na fisiopatogenia da gastrite e da doença ulcerosa péptica (DUP). Após a descoberta da relação patogênica entre este microorganismo e as doenças pépticas, a literatura revela que o curso da DUP teve um outro destino. Sabe-se, hoje, o quanto diminui a sua recidiva com a erradicação do H. pylori.

O tratamento do $H$. pylori por apenas sete a catorze dias cicatriza a maioria das úlceras pépticas gástricas e duodenais (COELHO, 2001; VAN DER HULST et al., 1996). O tratamento antimicrobiano também melhora o processo inflamatório crônico nas gastrites, após a erradicação do $H$. pylori.

Há relatos demonstrando que a erradicação do $H$. pylori no linfoma MALT, bem diferenciado e restrito à mucosa, é fundamental na cura desta patologia de potencial caráter maligno (MIYAJI et al., 1997; TALLEY et al., 1991; BLASER et al., 1993; PARSONNET et al., 1994). Mais recentemente, alguns estudos tentam comprovar a relação entre o $H$. pylori e o surgimento de inflamações crônicas do fígado. 
Observa-se uma prevalência significativa deste microorganismo nos pacientes com DPCF, mas este achado epidemiológico é insuficiente para propor uma relação etiopatogênica. Devem-se levar em consideração diversas variáveis que ainda não foram extensamente estudadas em cirróticos infectados pelo $H$. pylori. Dentre elas, faz-se mister avaliar melhor a etiologia da doença, o uso repetido de antibióticos, comum nestes pacientes, o grau de fibrose hepática e o grau de hipertensão portal. Esta última se torna de especial interesse pela possibilidade de favorecer infecçôes na mucosa gástrica, devido às alterações de fluxo sangüíneo causadas por esta hipertensão.

Após o conhecimento da existência de outras espécies de Helicobacter, a exemplo do $H$. hepaticus, em tecido hepático e soro, por método de PCR abrem-se novas perspectivas de estudar espécies de Helicobacter com hepatotropismo e, conseqüentemente, com maior chance de desempenhar papel etiopatogênico na in- flamação e na fibrose hepática (DORE et al., 2002). Nesse caso, substâncias pró-inflamatórias, tipo interleucinas, alfa TNF e outras, poderiam ser os mediadores do processo fibrogênico.

\section{CONCLUSÃO}

A literatura mostra uma significativa prevalência do $H$. pylori em pacientes com DPCF, associada com a presença de úlcera péptica. A participação desse microorganismo na patogenia da DPCF não está esclarecida, entretanto algumas evidências levam a supor mecanismos etiopatogênicos possivelmente relacionados à infecção pelo $H$. pylori no processo de agressão hepatocelular. No momento, a erradicação do $H$. pylori em portadores de doenças hepáticas só estaria indicada nos casos de gastrites erosivas e úlceras pépticas, seguindo exatamente a normatização dos consensos nacionais e internacionais sobre o tratamento desta infecção.

\title{
Prevalence and aetiopathogenic evidence of Helicobacter pylori in the chronic parenchymatous disease of the liver
}

\begin{abstract}
Helicobacter pylori is a bacterium which participates in the pathogeny of some gastro-duodenal diseases, such as gastritis, peptic ulcerous diseases and neoplasias of lymphoma MALT type. The eradication of that bacterium has been contributing to the control of those pathologies. At the moment, scientists are searching for evidences that demonstrate the relationship between the Helicobacter pylori and other diseases that are not gastro-duodenal. The objective of this study is to review the literature about the prevalence of infections by Helicobacter pylori in patients with chronic parenchymatous disease of the liver as well as those writings that suggest any aetiopathogenic participation of the Helicobacter pylori in the evolution of patients with chronic parenchymatous disease of the liver (DPCF). After analyzing the Medline database, from January, 1990 to December, 2002, we observed that several authors report a high prevalence of the Helicobacter pylori in patients with DPCF, however the number of samples and the adopted methodology have not been sufficient for external validation. Although the theoretical principles are clear, there is no proof that that bacterium contributes to the appearance of chronic inflammations in the liver or to the progression of hepatic fibrosis.
\end{abstract}

Keywords: Cirrhosis. Helicobacter pylori. 


\section{REFERÊNCIAS}

AL-KAREEMY, E. A. R.; ZAKHARY, M. M. Helicobacter pylori: is it a risk factor for hepatic encephalopathy in cirrhotic patients? Gut, London, v.39, p.121, 1996.

ALMEIDA, D. F. G. Estudo comparativo da prevalência de infecçôes bacterianas em pacientes cirróticos com hemorragia digestiva alta e sem hemorragia digestiva alta. 2000. Dissertação (Mestrado em Medicina Interna) Faculdade de Medicina, Universidade Federal da Bahia, Salvador, 2000.

ATTILI, A. F. et al. Helicobacter pylori: a major determinant of serum ammonia levels in cirrhotic patients? Hepatology, Baltimore, v.20, p.56, 1994.

AVENAUD, P. et al. Detection of Helicobacter species in the liver of patients with and without primary liver carcinoma. Cancer, New York, v.89, n.7, p.1431-1439, Oct. 2001.

BLASER, M. J. et al. Helicobacter pylori infection in Japanese patients with adenocarcinoma of the stomach. Int. J. Cancer, New York, v.55, n.5, p.799-802, Nov. 1993.

CALVET, X. et al. Evaluation of Helicobacter pylori diagnostic methods in patients with liver cirrhosis. Aliment. Pharmacol. Ther., Oxford, v.16, n.7, p.12831289, July 2002.

CALVET, X. et al. Seroprevalence and epidemiology of Helicobacter pylori infection in patients with cirrhosis. J. Hepatol., Oxford, v.26, n.6, p.1249-1254, June 1997.

CALY, W.; STRAUSS, E. A prospective study of bacterial infection in patients with cirrohisis. J. Hepatol., Oxford, v.18, n.3, p.353-358, July 1993.

CHAKRABARTI, P. et al. Helicobacter pylori, gastric juice, and arterial ammonia levels in patients with cirrhosis. J. Clin. Gastroenterol., New York, v.34, n.5, p.578-581, May/June 2002.

$\mathrm{CHO}$, Y. D. et al. The role gastric $\mathrm{H}$. pylori infection on the blood level of ammonia in patients with liver cirrhosis. Gastroenterology, Philadelphia, v.112, p.A 89, 1997.

COELHO, L. G.V. Úlcera péptica gastroduodenal. In: DANI, R. Gastroenterologia essencial. 2.ed. Rio de Janeiro: Guanabara Koogan, 2001. p.149-164.
CRABTREE, J. E.; FARMERY, S. M. Helicobacter pylori and gastric mucosal cytokines: evidence that CagA-positive strains are more virulent. Lab. Invest., Hagerstown, MD, v.73, n.6, p.742-745, Dec. 1995.

DE NARDO, S. et al. Diagnosis of cirrhosis and hepatitis by quantitative hepatic and other reticuloendothelial clearence rates. J. Nucl. Med., New York, v.34, n.17, p.449-459, 1996.

DEMIRTURK, L. et al. The effect of Helicobacter pylori eradication on gastric juice and blood ammonia concentrations and on visual evoked potentials in cirrhotics. Helicobacter, Cambridge, Mass., v.6, n.4, p.325-330, Dec. 2001.

DORE, M. P. et al. Helicobacter infection in patients with HCV-related chronic hepatitis, cirrhosis, and hepatocellular carcinoma. Dig. Dis. Sci., New York, v.47, n.7, p.1638-1643, July 2002.

DURAZZO, M. et al. Helicobacter pylori seroprevalence in patients with autoimmune hepatitis. Dig. Dis. Sci., New York, v.47, n.2, p.380-383, Feb. 2002.

EKSTRÖM, P. Non-gastric effects of H. pylori infection: a literature review with respect to non gastric diseases which might be associated with $\mathrm{H}$. pylori infection. Eur. J. Surg., Stockholm, Suppl.582, p.32-34, 1998.

FAGOONEE, S. et al. The journey from hepatitis to hepatocellular carcinoma: bridging role of Helicobacter species. Panminerva Med., Torino, v.43, n.4, p.279282, Dec. 2001. Review.

FALK SYMPOSIUM, 81., 1994, Berlin. Malignancy and chronic inflammation in the gastrointestinal tract: new concepts: new concepts: proceedings. Edited by E. O. Riecken et al. Boston: Kluwer Academic Publishers, 1995. p.25-36.

GALPERIN, C.; GERSHWIN, M. E. Immunopathogenesis of gastrointestinal and hepatobiliary diseases. JAMA: The Journal of the American Medical Association, Chicago, v.278, n.22, p.1946-1955, 1997.

KATAEV, S. S. et al. Campylobacter pylori in patients with liver cirrhosis of different etiologies. Arkh. Patol., Moskva, v.52, n.10, p.45-49, 1990. Texto em inglês.

KINI, D. et al. Role of Helicobacter pylori infection in hyperammonemia and subclinical hepatic encephalopathy in cirrhosis of liver. Indian. J. Gastroenterol., Bombay, v.20, n.6, p.237-240, Nov./Dec. 2001. 
KUIPERS, E. J.; THIJS, J. C.; FESTEN, H. P. M. The prevalence of Helicobacter pylori in peptic ulcer disease. Aliment. Pharmacol. Ther., Oxford, v.9, Suppl.2, p.5969, 1995.

MIQUEL, J. et al. Role of Helicobacter pylori infection and its eradication in patients with subclinical hepatic encephalopathy. Eur. J. Gastroenterol. Hepatol., London, v.13, n.9, p.1067-1072, Sept. 2001.

MIYAJI, H. et al. Effects of Helicobacter pylori eradication therapy on hyperammonaemia in patients with liver cirrhosis. Gut, London, v.40, p.726-730, 1997.

NILSSON, H. O. et al. Helicobacter species identified in liver from patients with cholangiocarcinoma and hepatocellular carcinoma. Gastroenterology, Philadelphia, v.120, n.1, Jan. 2001.

NILSSON, S.; LINDGREN, S.; WADSTRÖM, T. Serum antibodies to Helicobacter hepaticus and Helicobacter pylori in patients with chronic liver disease. Gut, London, v.46, p.410-414, 2000.

O'ROURKE, J. L.; GREHAN, M.; LEE, A. Non-pylori helicobacter species in humans. Gut, London, v.49, p.601-606, 2001.

PARSONNET, J.et al. Helicobacter pylori infection and gastric lymphoma. N. Engl. J. Med., Boston, v.330, p.1267-1271, 1994.

PELLICANO, R. et al. Helicobacter pylori seroprevalence in hepatitis $\mathrm{C}$ virus positive patients with cirrhosis. J. Hepatol., Oxford, v.33, n.4, p.648-650, Oct. 2000.

PEURA, D. A. DDW. International Update Conference on Helicobacter Pylori, May 14, 1997.

PLEVRIS, J. N. et al. Hyperammonaemia in cirrhosis and Helicobacter pylori infection. Lancet, London, v.346, n.8982, p.1104, Oct. 1995.

PONZETTO, A. et al. Helicobacter infection and cirrhosis in hepatitis $\mathrm{C}$ virus carriage: is it an innocent bystander or a troublemaker? Med. Hypotheses, Edinburgh, v.54, n.2, p.275-277, 2000.

RIMOLA, A . Infections in liver disease. In: MCINTYRE, Neil et al. (Ed.). Oxford textbook of clinical hepatology. Oxford: Oxford Medical Press, 1991.p.1272-1284.

ROSSLE, M. et al. Helicobacter pylori is not associated with an increased risk of hepatic encephalopathy. Hepatology, Baltimore, v.110, p.A 157,1994.
SCOTINIOTIS, I. A.; LUCEY, M. R.; METZ, D. C. Helicobacter pylori infection is not associated with subclinical hepatic encephalopathy in stable cirrhotic patients. Dig. Dis. Sci., New York, v.46, n.12, p.27442751, Dec. 2001.

SI, J. et al. Changes in serum ammonia concentration in cirrhotic patients with helicobacter pylori infection. Chin. Med. J., Peking, v.113, n.12, p.1080-1081, Dec.2000. Ediç̧ão em inglês.

SIRINGO, S. et al. High prevalence of Helicobacter pylori in liver cirrhosis: relationship with clinical and endoscopic features and the risk of peptic ulcer. Dig. Dis. Sci., New York, v.42, n.10, p.2024-2030, Oct. 1997.

SPINZI, G. et al. Helicobacter pylori seroprevalence in hepatitis $\mathrm{C}$ virus positive patients with cirrhosis: the Como cross-sectional study. Panminerva Med., Torino, v.43, n.2, p.85-87, June 2001.

STALKE, P. et al. Correlation between liver damage and degree of gastric mucose colonization by Helicobacter pylori in subjects with parenchymatous liver damage. Med. Sci. Monit., Warsaw, v.7, Suppl.1, p.271-276, May 2001.

TALLEY, N. J. et al. Gastric adenocarcinoma and Helicobacter pylori infection. J. Natl. Cancer Inst., Cary, NC, v.83, p.1734-1739, 1991.

TOLEDO, C. et al. Infecciones bacterianas en la cirrosis hepática. Rev. Med. Chil., Santiago, v.122, p.788-794, jul. 1994.

TSAI, C. J. Does quantitative serologic testing for Helicobacter pylori predict peptic ulcer disease in cirrhosis? Gastrointest. Endosc., St.Louis, MO, v.50, n.3, p.381386, Sept. 1999.

VAN DER HULST, R. W. M. et al. Treatment of Helicobacter pylori infection: a review of the world literature. Helicobacter, Cambridge, Mass., v.1, p.6-19, 1996.

VAN NIEUWKERK, C. M. J.;KUIPERS, E. J. Liver cirrhosis and peptic ulcer disease; a correlation with Helicobacter pylori? Neth. J. Med., Alphen aan de Rijn, v.56, p.203-205, 2000.

VERGARA, M.; CALVET, X.; ROQUÉ, M. Helicobacter pylori is a risk factor for peptic ulcer disease in cirrhotic patients: a meta-analysis. Eur. J. Gastroenterol. Hepatol., London, v.14, n.7, p.712-722, 2002. 
WARREN, J. R.; MARSHALL, B. Unidentified curved bacilli on gastric epithelium in active chronic gastritis. Lancet, London, n.8336, p.1273-1275, June 1983.

YOSHIDA, N. et al. Mechanisms involved in Helicobacter pylori infection. Gastroenterology, Philadelphia, v.105, p.1431-1440, 1995.
ZULLO, A. et al. Helicobacter pylori infection in dyspeptic cirrhotic patients. Hepato-gastroenteroly, Athens, v.46, n.25, p.395-400, Jan./Feb. 1999. 